\title{
PERSEPSI NILAI DAN KUALITAS LAYANAN TERHADAP PERILAKU KEWARGANEGARAAN PELANGGAN APLIKASI GO-JEK
}

\author{
Trevisia Meinar \\ trevisiameinar@gmail.com \\ Tatik Suryani \\ STIE Perbanas Surabaya
}

diterima: 29/6/2019; direvisi: 22/7/2019; diterbitkan: 31/8/2019

\begin{abstract}
This study aims to determine the effect of perceived value and perceived service quality by GoJek application users in Surabaya. The population in this study were all Go-Jek users throughout Indonesia. Samples were taken using a non-probability sampling method that specifically uses a purposive sampling technique. Based on the sampling technique, 200 samples were used in this study using Go-Jek in Surabaya. Data collection was carried out using a questionnaire that was distributed directly to respondents. The statistical method used as data analysis is PLS followed by WarpPLS 6.0. The results showed that customer satisfaction partially influenced mediation in service quality with customer citizenship behavior. In addition, customer satisfaction has a partial mediating effect on the perceived value by customer citizenship behavior.
\end{abstract}

Keywords: perceived value; service quality; customer citizenship behavior; Go-Jek

\begin{abstract}
Abstrak
Penelitian ini bertujuan untuk mengetahui pengaruh persepsi nilai dan kualitas layanan yang dirasakan oleh pengguna aplikasi Go-Jek di Surabaya. Populasi dalam penelitian ini adalah seluruh pengguna Go-Jek se-Indonesia. Sampel diambil menggunakan metode non-probability sampling yang secara spesifik menggunakan teknik purposive sampling. Berdasarkan teknik sampling tersebut, didapatkan sampel sebesar 200 orang yang menggunakan Go-Jek di Surabaya. Pengumpulan data dilakukan menggunakan kuesioner yang dibagikan langsung kepada responden. Metode statistik yang digunakan sebagai analisis data adalah PLS yang diikuti oleh WarpPLS 6.0. Hasil penelitian menunjukkan bahwa kepuasan pelanggan secara parsial mempengaruhi mediasi pada kualitas layanan dengan perilaku kewarganegaraan pelanggan. Selain itu, kepuasan pelanggan memiliki efek mediasi parsial pada nilai yang dipersepsikan dengan perilaku kewarganegaraan pelanggan.
\end{abstract}

Kata Kunci: persepsi nilai; kualitas layanan; perilaku kewarganegaraan pelanggan; Go-Jek 


\section{PENDAHULUAN}

Perkembangan teknologi informasi telah mengubah perilaku manusia dalam kegiatan mereka. Beragamnya semua aktivitas manusia di perkotaan telah menyadarkan masyarakat akan pentingnya kehadiran teknologi yang akan mendorong masyarakat untuk bertindak cepat, praktis, efektif, serta efisien. Pada Era ini kehadiran internet tidak lagi hanya sebagai media komunikasi tetapi kini sudah digunakan untuk berbagai aktivitas ekonomi dan sosial. Teknologi internet ini terus berkembang, didukung oleh pengembangan alat komunikasi digital seperti telepon genggam (smartphone) yang memiliki berbagai fungsi multimedia.

Berdasarkan penelitian yang dilakukan oleh $W e$ Are Social yang bekerjasama dengan Hootsuite, menyebutkan bahwa total populasi Indonesia adalah sebesar 265,4 juta jiwa, pada tahun 2018 pengguna internet telah mencapai setengah dari populasi penduduk di Indonesia, yakni sebesar 132,7 juta pengguna. Hal ini dapat disimpulkan bahwa penggunaan internet di Indonesia terus meningkat secara drastis. Dari jumlah itu, pengguna yang melakukan aktivitas internet via ponsel sama banyaknya, yaitu sebesar 120 juta pengguna di seluruh dunia.

Salah satu aspek yang mengikuti perkembangan teknologi informasi adalah bidang transportasi. Teknologi telah mempengaruhi aktivitas di industri transportasi, seperti misalnya pelayanan transportasi berbasis media online yang merupakan salah satu wujud dari adanya perkembangan teknologi tersebut. Aspek teknologi dalam transportasi yang telah berubah yaitu ditandai dengan adanya aplikasi transportasi online yang dapat di akses oleh pelanggan kapanpun dan dimanapun mereka berada. Beberapa tahun terakhir ini sedang berkembang aplikasi ojek online yang berbasis aplikasi yang dapat di akses melalui telepon genggam atau smartphone, aplikasi ini salah satunya adalah GoJek. Kondisi ini merupakan salah satu perkembangan baru bagi bidang transportasi online berbasis teknologi.

Go-Jek merupakan perusahaan teknologi dengan misi sosial untuk meningkatkan kesejahteraan dan mata pencaharian pekerja di berbagai sektor informal di Indonesia. Go-Jek mengedepankan 3 nilai penting, yaitu: kecepatan, inovasi, dan dampak sosial. Go-Jek kini beroperasi di 50 kota di seluruh Indonesia, dan berencana melakukan ekspansi pasar di lebih banyak kota untuk diikuti di tahun-tahun mendatang. Sebagai penyedia jasa transportasi berbasis online, Go-Jek menyediakan layanan transportasi menggunakan strategi pemasaran digital yang dapat diakses menggunakan smartphone oleh pelanggannya di manapun dan kapanpun konsumen berada. Kini teknologi transportasi terasa semakin dekat dengan kita, dan hanya sebatas di genggaman saja.

Menurut data ComScore per Desember 2017, tercatat sebanyak 15,73 juta orang menggunakan aplikasi transportasi online di ponsel Android. Di antaranya GoJek, Grab, dan Uber, yakni 29,6 persen dari seluruh pengguna aplikasi mobile. Satu dari empat pengguna internet di Indonesia memiliki aplikasi transportasi online di ponsel Androidnya, baik Go-Jek, Grab, mau pun Uber. Gambaran pengguna transportasi online dapat dilihat pada Gambar 1.

Mayoritas pengunjung dan pengguna Go-Jek berusia antara 25-34 tahun. Rata-rata penggunaan 69,5 menit per orang.Sedangkan, Grab paling banyak dikunjungi orang berusia 35 tahun ke atas. Namun, penggunanya didominasi usia 24-34 tahun dengan durasi pemakaian 64,4 menit per orang.Berbeda dengan lainnya, pengunjung Uber rata-rata berusia 25-34 tahun. Namun, penggunanya justru datang dari kalangan usia 35 tahun ke atas dengan waktu pemakaian 83,8 menit per orang.

Dalam upaya meningkatkan pelayanan kepada pelanggannya, Go-Jek berupaya untuk terus meningkatkan kualitas layanan (service quality) yang mereka miliki. Kualitas layanan keberadaannya sangat bergantung pada tiga hal, yaitu sistem, teknologi, dan sumber daya manusia. Dimensi kualitas layanan seperti tangibility, kehandalan, responsiveness, assurance, dan empati secara signifikan mempengaruhi kepuasan yang dirasakan oleh pelanggan (Agyapong, 2010).

Kualitas layanan yang diberikan oleh Go-Jek dapat digambarkan dalam 4 layanan yaitu: a. Fasilitas atau fitur adalah alat untuk membedakan produk perusahaan dengan pesaing. Go-Jek menyediakan fasilitas yang berbeda dengan para pesaingnya. Fitur dalam aplikasi Go-Jek juga memberikan informasi yang jelas bagi pelanggan untuk memilihlayanan apa yang di inginkan oleh pelanggan. Semua langkah dalam layanan pemesanan melalui digitalaplikasi mudah diikuti; b. Dalam hal kualitas Go-Jek selalu menempatkan keselamatan konsumensebagai prioritas pertama. Pelanggan akan merasa aman dan nyaman ketika mengambil layanan Transportasi menggunakan Go-Jek. Selain itu, Go-Jek Global Positioning System (GPS) akurat yang dapat digunakan pelanggan Untuk memonitor posisi pengemudi; c. Aplikasi digital Go-Jek mudah digunakan. Go-Jek memberikan fitur produk yang jelas. Ketika seorang pelanggan mengakses satu layanan yang diperlukan untuk memesan, tidak pernah tumpang tindih dengan layanan lain;d. Merek. Logo, nama, dan warna dibuat dominan di aplikasi Go-Jek sehingga mudah untuk di ingat oleh pelanggan. Selain itu, untuk membuat orang akrab dengan merek ini, kata Go-Jek juga tersedia di jaket para driver dan helm juga.

Faktor utama yang menyebabkan pelanggan bersedia menggunakan aplikasi Go-Jek adalah karena adanya kepuasan yang dirasakan ketika mengakses aplikasi GoJek tersebut. Selain itu, keputusan dari diri pengguna dalam menggunakan aplikasi Go-Jek juga dipengaruhi oleh persepsi nilai yang didapatkan pelanggan atas atas informasi, pengetahuan, dan kenyamanan yang 
didapatkan. Persepsi nilai yang didapatkan pelanggan merupakan hal penting yang akan menjadi pertimbangan oleh pelanggan dalam menggunakan aplikasi Go-Jek. Pada dasarnya, pelanggan akan memilih dan menerima dengan baik sebuah layanan yang dapat memberi mereka nilai serta manfaat. Semakin pengguna merasa aplikasi Go-Jek bermanfaat dan memiliki nilai, maka semakin sering intensitas mereka untuk mengaksesnya.

Dalam hal ini, kualitas layanan, persepsi nilai, dan kepuasaan pelanggan, secara tidak langsung akan mempengaruhi $C C B$ dalam penggunaan aplikasi Go-Jek. Cheng, Luo, Yen \& Yang dalam studinya menyatakan bahwa $C C B$ dapat mendorong pelanggan bersedia menawarkan produk, memberikan saran kepada pelanggan lain, dan memberikan umpan balik kepada perusahaan. $C C B$ terbukti memberikan manfaat dalam melindungi perusahaan dari permasalahan. Mempertimbangkan hubungan antara kepuasan pelanggan dan $C C B$ cukup logis, mengingat bahwa kepuasan pelanggan juga dapat berfungsi sebagai mediator untuk memperkuat hubungan antara kepuasan yang dirasakan pelanggan dengan $C C B$.

Jika perusahaan ingin menjangkau pelanggan, maka dibutuhkan adanya layanan. Layanan ini tergantung pada jenis produk yang dijual dan dapat berbeda-beda dari setiap perusahaan. Layanan dapat didefinisikan dalam banyak cara, tergantung pada dimana istilah tersebut digunakan. Ahli mendefinisikan layanan sebagai tindakan atau kinerja yang tidak berwujudyang ditawarkan satu pihak kepada pihak lain dan tidak menghasilkan kepemilikan apa pun (Kotler \& Keller, 2012).

Secara keseluruhan, layanan juga dapat didefinisikan sebagai tawaran tidak berwujud oleh satu pihak ke pihak lain dengan imbalan uang atau kesenangan. Kualitas adalah salah satu hal yang dicari konsumen dalam suatu penawaran dan layanan (Solomon, 2009). Kualitas juga dapat didefinisikan sebagai totalitas fitur dan karakteristik suatu produk atau layanan yang memiliki kemampuan untuk memenuhi kebutuhan yang dinyatakan atau tersirat (Kotler \& Keller, 2012). Kualitas juga terkait dengan nilai penawaran, yang dapat menimbulkan kepuasan atau ketidakpuasan pada pengguna atau pelanggan. Kualitas layanan dalam literatur manajemen dan pemasaran adalah sejauh mana persepsi pelanggan tentang layanan memenuhi dan atau melebihi harapan mereka sesuai dengan perkembangan yang ada.

Dengan demikian kualitas layanan dapat menjadi cara sebuah organisasi melayani pelanggannya secara baik atau buruk. Parasuraman mendefinisikan kualitas layanan sebagai perbedaan antaraharapan pelanggan dan persepsi layanan (Parasuraman, 1988). Mereka berpendapat bahwa mengukur kualitas layanan sebagai perbedaan antara layanan yang dirasakan dan yang diharapkan adalah cara yang paling valid dan dapat membuat perusahaan mengidentifikasi kekurangan apa yang mereka miliki ketika menawarkan layanan pada pelanggan yang menggunakan aplikasi.

Tujuan menyediakan layanan berkualitas adalah untuk memuaskan pelanggan. Mengukur kualitas layanan adalah cara yang lebih baik untuk menentukan apakah layanan tersebut baik atau buruk, dan apakah pelanggan akan atau puas dengan layanan yang kita berikan. Sebuah peneliti menyebutkan bahwa ada tiga komponen penting dari kualitas layanan yang tercantum dalam studinya. Dalam studi tersebut, kualitas layanan digambarkan terdiri dari tiga elemen, meliputi: a)Fasilitas, proses dan prosedur fisik; b) Perilaku pribadi pada bagian staf yang melayani, dan; c) Penilaian profesional pada bagian staf yang melayani tetapi untuk mendapatkan layanan berkualitas baik.

Lima perspektif kualitas layanan yang telah diidentifikasi oleh Parasuraman et al. (1988) adalah sebagai berikut: a) Tangibles - koordinasi antara sumber daya manusia, kenyamanan dan peralatan. b) Empati - lebih banyak perhatian terhadap hal-hal individual dan perhatian tentang pelanggan. c) Responsiveness bagaimana cara mereka untuk menyampaikan keyakinan dan kepercayaan diri dihadapan konsumen; d) Reliabilitas - potensi lembaga, organisasi dan karyawan untuk melaksanakan layanan dengan cara yang benar dan menjanjikan; e) Ketanggapan - kemauan karyawan untuk membantu pelanggan saat mereka membutuhkan dan memberikan layanan cepat kepada mereka.

Nilai yang dirasakan telah mendapatkan perhatian yang cukup besar dalam literatur pemasaran jasa (Boksberger \& Melsen, 2011). Hal ini dianggap sebagai dasar fundamental untuk semua aktivitas pemasaran (Holbrook, 1994: 22). Nilai yang dirasakan secara umum didefinisikan sebagai penilaian menyeluruh konsumen terhadap kegunaan suatu produk (atau layanan) berdasarkan pada persepsi tentang apa yang diterima dan apa yang diberikan (Parasuraman \& Zeithaml, 1988).

Demikian pula, McDougall dan Levesque (2000) mendefinisikan nilai yang dirasakan sebagai manfaat yang diterima relatif terhadap biaya. Definisi ini mewakili perspektif kegunaan dari nilai yang dirasakan, yang membahas perbedaan antara manfaat yang diterima dan biaya yang diberikan. Youjae et al. (2014) mepersepsi nilai pelanggan terhadap layanan yang diperoleh terkait dengan harga yang dibayarkan terhadap layanan tertentu. Sebagian besar penelitian menilai bahwa nilai yang dirasakan berfokus pada nilai untuk uang.

Mengikuti definisi ini, nilai yang dirasakan adalah perantara dari manfaat yang dirasakan dari layanan oleh pelanggan, dan berdasarkan perbedaan antara apa yang mereka berikan dalam hal waktu, usaha, dan uang, serta apa yang mereka terima dari kinerja layanan yang diberikan kepada mereka. Nilai yang dirasakan adalah salah satu yang memiliki banyak faktor penting yang mempengaruhi daya saing organisasi (Ravald 
dan GroÈnroos, 1996; Parasuraman, 1998). Oleh karena itu tidak mengherankan untuk bahwa sejumlah penelitian mengungkapkan adanya hubungan positif antara nilai yang dirasakan dan kepuasan pelanggan di berbagai bidang konteks layanan. Bukti empiris juga menunjukkan bahwa nilai yang dirasakan dari sebuah layanan dapat dipengaruhi oleh variabel seperti kualitas layanan dan emosi konsumen (Deng et al., 2013; Yoon et al., 2010).

Nilai yang dirasakan sering kali dengan mudah disamakan dengan kepuasan, namun kedua hal ini sebenarnya berbeda. Nilai yang dirasakan terjadi pada berbagai tahap proses pembelian, termasuk tahap prapembelian (Woodruff,1997), sedangkan kepuasan secara universal disepakati sebagai evaluasi pasca pembelian dan pascabayar. Sebagai konsekuensinya, persepsi nilai dapat dihasilkan tanpa produk atau layanan yang dibeli atau digunakan, sementara kepuasan tergantung pada pengalaman memiliki menggunakan produk atau layanan.

Sebagian besar definisi menyatakan nilai yang dirasakan pelanggan sebagai trade-off antara manfaat dan pengorbanan yang dirasakan oleh pelanggan terhadap layanan perusahaan (Parasuraman, 1988). Manfaat yang dirasakan adalah kombinasi atribut fisik, atribut layanan, dan dukungan teknis yang tersedia dalam kaitannya dengan situasi penggunaan tertentu. Persepsi nilai yang dirasakan adalah konstruk yang dirasakan secara subyektif, misalnya segmen pelanggan yang berbeda merasakan nilai yang berbeda di dalam produk yang sama. Selain itu, berbagai anggota dalam organisasi pelanggan terlibat dalam proses pembelian yang sama namun juga dapat memiliki persepsi yang berbeda. Persepsi nilai yang bersifat relatif terhadap persaingan dapat memberikan trade-off yang lebih baik antara manfaat dan pengorbanan dalam suatu produk atau layanan. Penawaran yang lebih baik nilainya lebih unggul daripada sekedar kompetisi, hal ini akan membantu perusahaan untuk menciptakan keunggulan kompetitif yang berkelanjutan.

Tujuan utama organisasi adalah untuk memaksimalkan keuntungan dan meminimalkan biaya. Maksimalisasi keuntungan bisa dicapai melalui peningkatan penjualan dengan biaya yang lebih rendah. Salah satu faktor yang dapat membantu meningkatkan penjualan adalah kepuasan pelanggan. Kepuasan akan selalu mengarah pada rekomendasi, kesetiaan pelanggan, dan pembelian ulang (repurchase).

Secara garis besar Kepuasan konsumen dikonseptualisasikan sebagai emosional atau respon kognitif manusia (Joan \& Joseph, 2000). Kepuasan pelanggan adalah faktor paling penting yang mempengaruhi manajemen layanan. Kepuasan pelanggan dapat berupa pembelian berulang (repurchase) dan rekomendasi dari mulut ke mulut (WOM), maka kepuasan pelanggan dianggap penting untuk semua bisnis. Menurut Dube et al. (1994), kepuasan pelanggan adalah indikator apakah pelanggan akan kembali ke tempat tersebut atau kepuasan pelanggan adalah merupakan sebuah kriteria yang utama untuk menentukan kualitas yang sebenarnya dikirimkan ke pelanggan melalui produk/jasa dan dengan layanan yang menyertainya.

Pelanggan terbiasa membeli produk atau layanan dengan berdasarkan harapan dari pengalaman sebelumnya. Dengan kata lain, sebelum mereka membeli produk atau layanan, pelanggan sudah memiliki tingkat harapan tertentu. Kemudian, begitu mereka membeli produk atau layanan, mereka membandingkan produk yang baru dengan produk atau layanan sebelumnya. Pada saat ini, konfirmasi atau diskonfirmasi terjadi. Jika pelanggan dapat menerima hasil dibandingkan dengan harapannya, konfirmasi akan terjadi. Di sisi lain, jika pelanggan tidak dapat menerima hasil, diskonfirmasi akan terjadi. Ada dua jenis diskonfirmasi, yaitu diskonfirmasi positif dan negatif diskonfirmasi. Ketika hasil dari produk atau layanan kurang daripada yang diharapkan pelanggan, diskonfirmasi negatif akan terjadi. Di sisi lain tangan, ketika pelanggan merasa lebih baik tentang hasilnya daripada harapan, disconfirmation positif akan terjadi. Singkatnya, kepuasan pelanggan terjadi dengan konfirmasi atau diskonfirmasi positif dari harapan konsumen, dan dari ketidakpuasan terjadi oleh diskonfirmasi negatif dari harapan konsumen (Van Tonder et, al. 2018).

Membangun kepuasan telah mendapatkan peran penting dalam literatur pemasaran dan diterima secara luas oleh peneliti sebagai prediktor untuk memperkuat variabel perilaku seperti niat pembelian kembali (repurchase intention), dari mulut ke mulut (WOM), atau kesetiaan (loyalty) (Ravald dan GroÈnroos, 1996; Liljander dan Strandvik, 1995). Penelitian kepuasan pelanggan terutama dipengaruhi oleh diskonfirmasi paradigma (Parasuraman et al., 1988). Paradigma ini menyatakan bahwa perasaan kepuasan pelanggan adalah hasil dari proses perbandingan antara kinerja yang dirasakan dan satu atau lebih standar perbandingan, seperti harapan. Pelanggan puas ketika dia merasa bahwa produk itu kinerjanya sama dengan apa yang diharapkan (mengkonfirmasikan). Jika produk tersebut kinerjanya melebihi harapan, pelanggan sangat puas (positive disconfirming), jika tetap di bawah harapan, pelanggan akan merasa tidak puas (negative disconfirming)

Sebagian besar peneliti sepakat pada paradigma diskonfirmasi, sifat kepuasan tetap tidak jelas. Di satu sisi, kepuasan jelas muncul dari proses kognitif membandingkan kinerja yang dirasakan terhadap beberapa standar perbandingan. Di sisi lain, perasaan puas dasarnya mewakili keadaan pikiran yang afektif. Akibatnya, beberapa skala kepuasan menyentuh dimensi kognitif dari kepuasan, sementara yang lain menangkap sifat afektifnya. Sejauh mana skala kepuasan berfokus pada dimensi kognitif atau afektif, bagaimanapun, harus memiliki dampak baik dari pendahulunya yang 
mempengaruhi kepuasan dan konsekuensinya dipupuk oleh kepuasan. Keputusan yang jelas tentang sifat dasar konstruk kepuasan dibutuhkan (Eggert \& Ulaga 2002).

Eugene (1994) menyebutkan beberapa manfaat utama dari kepuasan pelanggan yang tinggi bagi perusahaan. Secara umum, kepuasan pelanggan yang tinggi harus menunjukkan peningkatan loyalitas untuk pelanggan saat ini, dan reputasi yang ditingkatkan untuk perusahaan. Meningkatnya loyalitas pelanggan saat ini berarti lebih banyak pelanggan yang akan melakukan pembelian kembali di masa depan.

Konsep Customer Citizenship Behavior (CCB) didasarkan pada teori pertukaran sosial. Menurut teori ini, orang-orang berpartisipasi dalam serangkaian interaksi interdependen yang mengarah pada kewajiban di antara para pihak pertukaran. Orang-orang yang telah merasakan manfaat dari pihak tertentu mungkin merasa berkewajiban untuk membalas budi pada pihak tersebut (Cropanzano, 2012).

Menerapkan teori pada lingkungan bisnis jasa dapat berarti bahwa pelanggan yang mengalami pengalaman positif akan membalas budi, tanpa biaya tambahan, dengan menampilkan $C C B$. Menurut Bove et al. (2009), $C C B$ termasuk tindakan seperti perilaku positif dari mulut ke mulut (komunikasi informal yang menguntungkan tentang aspek organisasi), hubungan afiliasi (menggunakan tampilan yang nyata atau barangbarang pribadi untuk mengkomunikasikan hubungan dengan organisasi), saran untuk layanan perbaikan (tidak terkait dengan contoh konsumsi spesifik), pemolisian pelanggan (memastikan perilaku yang sesuai), perilaku menyuarakan (mengkomunikasikan kegagalan layanan kepada organisasi untuk perbaikan), bersikap fleksibel (kesediaan untuk beradaptasi dengan situasi), tindakan pelayanan yang baik (amal), fasilitasi dan mengambil bagian dalam kegiatan organisasi (seperti penelitian atau kegiatan bersponsor lainnya).

Dalam studi komprehensif lainnya tentang subjek, kemudian mengembangkan dan memvalidasi halhal berikut sebagai dimensi-dimensi penting $C C B$, seperti: umpan balik kepada perusahaan, menganjurkan manfaat layanan kepada pelanggan lain, membantu pelanggan lain dengan layanan dan toleran dengan tingkat pemberian layanan. Dari berbagai dimensi yang diidentifikasi, jelas bahwa $C C B$ terkait dengan perilaku pelanggan dan peran-positif yang akan berkontribusi pada organisasi menjadi lebih berhasil (Gilde et al. 2011).

Menurut Van Tonder et, al. (2018), ada dua dimensi $C C B$ yang dianggap dapat mewakili bentuk $C C B$ yang relevan dalam lingkungan internet dan dapat membantu mengatasi masalah adopsi lambat yang dialami dalam industri elektronik.

Advokasi konsumen terkait dengan perilaku pembelaan konsumen tetapi masih merupakan bagian dari dalam dirinya sendiri (Chelminski \& Coulter 2011: 362). Permasalahan advokasi meliputi percakapan dengan teman dan keluarga di mana konsumen mendukung perusahaan jasa dan mungkin termasuk memberikan komentar positif tentang perusahaan, serta memberikan rekomendasi layanan dan dorongan untuk menggunakannya. Perilaku sukarela yang ditampilkan melalui kata-dari-mulut positif dapat menghasilkan sejumlah manfaat bagi perusahaan, termasuk citra positif dan basis pelanggan yang diperluas.

Perilaku membantu konsumen adalah hal yang sebagian besar telah diabaikan dalam riset pemasaran. Tampaknya beberapa konsumen berpendapat bahwa itu adalah tanggung jawab mereka untuk membantu konsumen lain (Chelminski \& Coulter 2011). Ada juga persepsi bahwa konsumen membantu satu sama lain karena itu bermanfaat. Dengan demikian, beberapa konsumen menikmati terlibat aktif dalam membantu konsumen dan berbagi informasi belanja mereka sendiri dengan konsumen lain. Konsumen dapat membantu konsumen lain agar memungkinkan mereka memiliki pengalaman positif yang sama di pasar konsumen (Chelminski \& Coulter 2011). Umumnya, konsumen dapat menerima bantuan dari sesama konsumen dalam mencari produk, memperbaikinya, atau menggunakannya dengan benar.

Teori pertukaran sosial menunjukkan bahwa pengalaman pelanggan yang positif kemungkinan besar akan memotivasi pelanggan untuk membalas budi dengan terlibat dalam perilaku sukarela (Bettencourt, 1997). Selain itu, individu cenderung untuk terlibat dalam $C C B$ (Lawler, 2001) ketika terjadi pertukaran sosial yang sukses. Seseorang yang mempersepsikan pengalaman merasakan kualitas tinggi terhadap suatu jasa, dalam suatu hubungan pelanggan kemungkinan akan membalas dan bertindak secara kooperatif Bettencourt (1997).

Tingkat pengalaman pelanggan tehadap kualitas layanan yang lebih tinggi atau lebih rendah diharapkan dapat menyebabkan peningkatan atau penurunan $C C B$. Menurut literatur sebelumnya, menunjukkan bahwa kualitas layanan dari pengalaman pelanggan memiliki pengaruh positif pada $C C B$.

Beberapa studi empiris telah meneliti fakta yang mempengaruhi CCB. Menurut Youjae (2014), nilai yang dirasakan pelanggan dianggap sebagai salah satu fakta yang berpengaruh paling signifikan terhadap $C C B$. Nilai yang dirasakan oleh pelanggan menangkap nilai keseluruhan atau manfaat yang diterima pelanggan dari terlibat dalam proses pemberian layanan. Semakin banyak pelanggan yang terlibat dalam $C C B$, semakin banyak nilai yang akan mereka terima dan rasakan (Yi \& Gong, 2013).

Sementara pelanggan yang menunjukkan $C C B$ melibatkan lebih banyak interaksi antara pelanggan ke pelanggan, hal itu diharapkan dapat berkontribusi untuk menciptakan nilai yang lebih baik dalam lingkungan layanan. Oleh karena itu, pelanggan akan mengalami nilai yang dirasakan lebih besar sejauh perilaku tersebut 
dilakukan. Misalnya, pelanggan yang telah dibantu oleh pelanggan lain dapat mengambil manfaat dari perilaku membantu tersebut dan menerima nilai layanan yang lebih besar. Dalam penelitian Lengnick-Hall et al. (2000) juga menemukan pengaruh yang signifikan dan positif dari $C C B$ terhadap manfaat yang diterima pelanggan.

Menurut Tam (2000), ada hubungan erat antara kualitas layanan dan kepuasan pelanggan. Kualitas layanan dianggap sebagai faktor penting dalam meningkatkan kepuasan dan loyalitas pelanggan, pentingnya kualitas layanan telah dipelajari oleh akademisi dan praktisi.

Kualitas layanan telah diakui berperan penting dalam meningkatkan laba perusahaan karena terkait langsung untuk kepuasan pelanggan, dan kesetiaan pelanggan (Baker \& Crompton, 2000; Leal \& Pereira, 2003; Zeithaml \& Bitner, 2000). Bahkan, banyak peneliti telah mempelajari bagaimana cara melakukan pengukuran kualitas layanan. Yang paling terkenal instrumen untuk mengukur kualitas layanan adalah SERVQUAL, yang diperkenalkan oleh Parasuraman et al. (1988). Sejak diperkenalkan, SERVQUAL telah banyak diterapkan di banyak industri untuk mengukur persepsi pelanggan terhadap kualitas layanan (Parasuraman, Berry, \& Zeithaml, 1991). Parasuraman et al. (1988) menyarankan bahwa persepsi pelanggan tentang kualitas layanan dapat diukur dengan kesenjangan antara harapan dan persepsi pelanggan tingkat kinerja. SERVQUAL terdiri dari lima dimensi berbeda dengan 29 pernyataan operasi spesifik. Dimensinya adalah: assurance (pengetahuan) dan kesopanan karyawan dan kemampuan mereka untuk menginspirasi kepercayaan dan keyakinan), empati (perhatian yang peduli dan individual yang diberikan perusahaan kepada pelanggannya), keandalan (kemampuan untuk melakukan layanan yang dijanjikan dengan andal dan akurat), tanggap (keinginan untuk membantu pelanggan dan memberikan umpan balik).

Teori tersebut sejalan dengan penelitian Helena et al (2014) yang menyatakan bahwa terdapat interaksi yang saling berhubungan antara kualitas layanan dengan $C C B$. Kualitas layanan yang baik akan cenderung untuk memunculkan intention to return dan provide feedback.

Beberapa penelitian menunjukkan bahwa pelanggan yang menganggap bahwa mereka menerima value for money akan lebih puas daripada pelanggan yang tidak merasa bahwa mereka menerima value for money (Parasuraman, 1988). Persepsi nilai juga dapat digunakan oleh konsumen untuk berbagai aspek layanan yang relatif terhadap penawaran kompetitif. Nilai yang dirasakan akan didefinisikan sebagai penilaian keseluruhan konsumen tentang apa yang diterima terhadap apa yang diberikan.

Hubungan antara persepsi nilai dan kepuasan pelanggan atau niat pembelian di masa depan telah diperdebatkan dalam berbagai literatur service marketing. Sementara itu, para ahli berpendapat bahwa persepsi nilai pelanggan memiliki dampak langsung pada seberapa puas pelanggan dengan perusahaan jasa.

Dalam penelitian Jamshidi et, al. (2018), ditemukan bahwa konstruk persepsi nilai secara signifikan dan positif mempengaruhi kepuasan pelanggan, dan hal ini dapat memberikan pengaruh positif terhadap loyalitas dari pelanggan. Selain itu, persepsi nilai memainkan peran penting dalam menentukan kepuasan pelanggan. Dengan menetapkan peran dari nilai yang dirasakan, keputusan yang dirancang untuk meningkatkan kepuasan pelanggan akan dianggap lebih efektif (McDougall, et al. 2000).

Beberapa peneliti berpendapat bahwa kepuasan pelanggan dapat mempengaruhi $C C B$ (Anaza \& Zhao 2013). Hubungan antara kepuasan pelanggan dan $C C B$ yang dihasilkan dapat dijelaskan oleh teori pertukaran sosial. Pelanggan yang puas dengan perusahaan cenderung percaya bahwa perusahaan telah memenuhi kewajiban kontraktualnya untuk memberikan layanan prima terhadap pelanggan. Dengan demikian, pelanggan mungkin ingin membalas budi dengan terlibat dalam perilaku CCB (Anaza \& Zhao, 2013). Hubungan positif antara kepuasan pelanggan dan $C C B$ biasanya melibatkan rekomendasi pelanggan dan perilaku membantu, juga telah dicatat dalam literatur akademik.

Secara khusus, efek dari komitmen afektif pada perilaku $C C B$ dapat dijelaskan oleh ikatan emosional yang dirasakan oleh konsumen yang berkomitmen tinggi terhadap perusahaan, dan sejauh mana mereka mengidentifikasi tujuan dan nilai-nilai perusahaan. Pelanggan yang memiliki perasaan keterikatan secara emosional cenderung khawatir tentang kesejahteraan perusahaan dan akan bersedia membalas usahanya dengan menampilkan perilaku $C C B$ (Yi \& Gong 2013).

Penjelasan dari teori diatas ditemukan sejalan dengan penelitian dari Van Tonder et, al. (2018) bahwa ditemukan adanya pengaruh yang signifikan antara kepuasan pelanggan dengan $C C B$ (Advocacy dan Helping). Penelitian ini juga memberikan bukti bahwa perilaku sukarela $(C C B)$ mungkin tidak hanya terikat pada kepuasan saja namun juga dapat dipengaruhi oleh keterikatan emosional dan komitmen dari pelanggan.

Dari beberapa tinjauan literatur, kepuasan pelanggan dipercaya dapat memediasi hubungan antara kualitas layanan dan $C C B$. Komunikasi WOM positif di antara pelanggan adalah perilaku yang menunjukkan ketertarikan dan loyalitas konsumen kepada perusahaan dan dapat meningkatkan citra perusahaan dan meningkatkan harapan dan evaluasi kualitas layanan pelanggan. Sehingga semakin puas pelanggan terhadap layanan perusahaan, maka semakin tinggi pula perilaku $C C B$ yang akan ditimbulkan.

Perilaku $C C B$ pelanggan menekankan efek positif dari WOM, kerjasama, partisipasi, dan perilaku altruisme lainnya. Dalam melakukannya, ini menggarisbawahi bagaimana beragam jenis perilaku kewarganegaraan pelanggan meningkatkan kinerja perusahaan dan 
menguntungkan pelanggan lainnya, hal ini juga menawarkan contoh mengapa dan bagaimana pelanggan dapat menjadi sumber kompetensi yang penting bagi perusahaan.Kerja sama pelanggan, partisipasi, dan perilaku altruisme juga dapat membantu mengurangi biaya perusahaan, mempertahankan atau meningkatkan kualitas layanannya, dan meningkatkan kepuasan pelanggannya (Fowler, 2013). Kerangka pemikiran ditunjukkan pada Gambar 2.

\section{METODE}

Populasi dari penelitian ini adalah seluruh pengguna aplikasi Go-Jek Indonesia sebanyak lima puluh juta orang. Sampel dalam penelitian ini adalah seluruh pengguna aplikasi Go-Jek di Surabaya, sedangkan teknik pengambilan sampel dalam penelitian ini menggunakan non probabilitas (non-probability sampling method/ non-randomly sampling). Dalam penelitian ini untuk kebutuhan penelitian ditetapkan sampel sebesar 200 sampel. Adapun penarikan sampel non probabilitas dalam penelitian ini dilakukan dengan cara judgment sampling yaitu peneliti menggunakan pertimbangan berdasarkan kriteria tertentu agar telah benar-benar sesuai dengan penelitian yang akan dilakukan oleh peneliti. Anggota populasi dipilih oleh peneliti sendiri sehingga tidak ada populasi lain untuk menjadi sampel diluar pertimbangan peneliti. Calon responden harus memiliki kriteria tertentu sesuai keinginan peneliti, adapun sampel dalam penelitian ini harus berusia minima 18 tahun,telah menggunakan aplikasi Go-Jek minimal 1 bulan lamanya, dan bertempat tinggal di Surabaya.

\section{HASIL}

Analisis data yang digunakan adalah Warp-PLS versi 6.0. Analisis data dengan PLS dilakukan dengan menilai outer model dan inner model. Outer model dilakukan untuk menilai validitas dan reliabilitas model. Sedangkan inner model bertujuan untuk memprediksi hubungan antar variabel laten, dan melihat uji pengaruh dengan melihat nilai T-statistic.

Langkah pertama analisis data dengan program Warp-PLS adalah evaluasi outer model, yaitu spesifikasi atau persyaratan hubungan antara variabel laten dengan indikatornya yang bersifat reflektif.

Uji validitas ini dilakukan untuk menguji suatu konstruk mempunyai unidimensionalitas atau apakah indikator-indikator yang digunakan dapat mengkonfirmasi sebuah konstruk atau variabel.

Output dari program WarpPLS yaitu loading factors dan cross loadings digunakan untuk menunjukkan hasil pengujian validitas konvergen dari instrumen pengukuran. Menurut Boksberger, et, al. (2011) terdapat dua kriteria untuk menilai apakah outer model memenuhi syarat validitas konvergen dan validitas diskriminan untuk konstruk reflektif, yaitu (1) loading factor atau muatan faktor harus di atas 0,7 dan (2) nilai $p$ signifikan $(p<0,005)$. Sementara itu, menurut Solimun, dkk. (2017:115), muatan faktor lebih besar atau sama dengan 0,5 hingga 0,6 dianggap cukup sebagai kriteria terpenuhinya validitas konvergen. Semua variabel tersebut didukung indikator-indikator yang memiliki loading factor $>0,5$ dan dengan masingmasing dukungan signifikansi $(\mathrm{p})<0,05$ sehingga telah memenuhi syarat validitas konvergen yang baik.

Berdasarkan hasil perhitungan untuk uji validitas konvergen, didapatkan nilai variabel Kualitas layanan memiliki loading factor antara 0,726 sampai dengan 0,814 dengan masing-masing dukungan signifikansi (p) $<0,001$ sehingga kualitas layanan memiliki validitas yang baik. Variabel Persepsi nilai memiliki loading factor antara 0,736 sampai dengan 0,786 dengan masing-masing dukungan signifikansi $(\mathrm{p})<0,001$ sehingga persepsi nilai memiliki validitas yang baik. Variabel Kepuasan pelanggan memiliki loading factor antara 0,680 sampai dengan 0,802 dengan masingmasing dukungan signifikansi $(p)<0,001$ sehingga kepuasan pelanggan memiliki validitas yang baik. Variabel Customer Citizenship Behavior (CCB) memiliki loading factor antara 0,734 sampai dengan 0,832 dengan masing-masing dukungan signifikansi (p) $<0,001$ sehingga Customer Citizenship Behavior $(C C B)$ memiliki validitas yang baik.

Kriteria validitas diskriminan yaitu nilai loading factor indikator terhadap konstruk harus lebih besar dibandingkan nilai loading factor indikator kepada konstruk lainnya (Solimun, 2017:115). Berdasarkan hasil perhitungan program Warp-PLS, diketahui bahwa elemen indikator KL-1 sampai dengan KL-5 memiliki loading factor terbesar pada konstruk laten Kualitas layanan. Elemen indikator PV-1 sampai dengan PV-5 memiliki loading factor terbesar pada konstruk laten persepsi nilai. Elemen indikator KP-1 sampai dengan KP-5 memiliki loading factor terbesar pada konstruk laten Kepuasan pelanggan. Terakhir, elemen indikator $C C B 1$ sampai dengan $C C B 8$ memiliki loading factor terbesar pada konstruk laten Customer Citizenship Behavior (CCB). Dengan demikian, maka setiap konstruk serta variabel laten yang digunakan pada penelitian ini telah didukung oleh indikator-indikator yang telah memenuhi kriteria validitas diskriminan secara baik.

Parameter lain yang digunakan untuk melihat validitas konvergen adalah dengan melihat nilai Average Variance Extracted (AVE). Disarankan nilai AVE harus $>0,50$. Nilai AVE yang didapat dari output model adalah sebagai berikut:

Berdasarkan Tabel 1, AVE pada variabel laten kualitas layanan sebesar $0,613(>0,5)$, Persepsi nilai sebesar 0,588 $(>0,5)$, Kepuasan pelanggan sebesar $0,563(>0,5)$, dan $C C B$ sebesar 0,635 (>0,5). Hasil tersebut memperlihatkan bahwa nilai AVE masing- 
masing indikator sudah memenuhi kriteria dengan nilai AVE sebesar $>0.5$ bedasarkan hasil perhitungan statistk yang telah dilakukan.

Uji reliabilitas dilakukan untuk menguji reliabilitas suatu konstruk. Uji reliabilitas dilakukan untuk membuktikan akurasi, konsistensi dan ketepatan instrument dalam mengukur konstruk (Ghozali, 2012:79).

Uji reliabilitas dilakukan dengan melihat nilai composite reliability dan Cronbach's Alpha. Nilai composite reliability dianggap baik jika nilainya $>$ 0,70 dan Cronbach's Alpha disarankan di atas 0,60. Berdasarkan hasil perhitungan pada Tabel 2, tampak bahwa kualitas layanan memiliki reliabilitas sebesar 0,888 , persepsi nilai memiliki reliabilitas sebesar 0,877 , kepuasan pelanggan memiliki reliabilitas sebesar 0,865 , serta Customer Citizenship Behavior (CCB) memiliki reliabilitas sebesar 0,933. Berdasarkan nilai Composite Reliability, masing-masing variabel telah memenuhi kriteria reliability yang baik. $(>0,7)$. Selanjutnya, besarnya hasil perhitungan Cronbach Alpha (CA) dimana $\alpha$ pada Kualitas layanan sebesar 0,842 , $\alpha$ pada Persepsi nilai sebesar $0,804, \alpha$ pada Kepuasan pelanggan sebesar 0,918, a pada Customer Citizenship Behavior $(C C B)$ sebesar 0,914 menurut hasil perhitungan statistik pada penelitian ini.

Sebelum dilakukan interpretasi terhadap hasil pengujian hipotesis, maka model seharusnya memiliki Goodness of Fit yang baik. Setelah evaluasi ini memenuhi persyaratan yang baik, maka langkah analisis data dilakukan dengan melakukan evaluasi atas pembuktian hipotesis penelitian.

Output umum dari program WarpPLS memberikan hasil model fit indices dan P values menampilkan hasil tiga indikator fit yaitu average path coefficient (PC), Average $R$-Squared (ARS), dan Average variance inflation factor (AVIF).

Hasil output pada Tabel 3 menunjukkan bahwa kriteria Goodness Of Fit pada model persamaan struktural telah memenuhi kriteria. Nilai $\mathrm{P}$ value untuk Average Path Coefficient (APC) adalah 0,005 $(<0,05)$ yang berarti terdapat perbedaan pada tanda koefisien jalur. ARS dan AARS didukung dengan nilai signifikan $(<0,05)$ yang artinya kontribusi variabel-variabel laten yang satu bernilai signifikan dalam perubahan variabel laten lainnya. Sementara itu, AVIF sebesar 1,200 (< 3,3 ) yang menunjukkan bahwa model telah bebas dari gejala multikolinieritas.

Tabel 4 menunjukkan variabel laten kepuasan pelanggan memiliki $R$-Square sebesar 0344 yang artinya bahwa pengaruh kualitas layanan dan persepsi nilai dapat memprediksi 34,4\% dari kepuasan pelanggan. Nilai $R$-Square dari variabel $C C B$ sebesar 0,235 berdasarkan hasil perhitungan. Nilai ini juga menunjukkan bahwa pengaruh kualitas layanan, persepsi nilai, dan kepuasan pelanggan dapat memprediksi $23,5 \%$ dari $C C B$. Besaran yang didapat pada nilai $R$-Square ini telah memenuhi syarat nilai $R$-Square $>0$. (Ghozali dan Hengky, 2012:82). Kepuasan pelanggan memiliki Q-Square sebesar 0,345 dan $C C B$ sebesar 0,238 yang berarti semua variabel telah memenuhi syarat nilai Q-Square $>0$ sehingga telah memenuhi Goodness of Fit yang baik. Nilai 0,345 pada Q2 menunjukkan bahwa model kuat, sedangkan nilai 0,238 menunjukkan bahwa model moderate (Ghozali dan Hengky, 2012:84).

Berdasarkan hasil klasifikasi koefisien jalur pada Tabel 5, tampak bahwa jalur-jalur yang membentuk hipotesis penelitian ini telah terlihat besaran dan tingkat signifikansinya. Pengaruh antar variabel berdasarkan analisis SEM dengan Warp-PLS tersebut bila dirinci sebagai berikut: (1) Kualitas layanan berpengaruh langsung sebesar 0,404 terhadap $C C B$. Pengaruh langsung yang positif ini signifikan karena dukungan $\mathrm{p}$ value sebesar 0,022 nilainya lebih kecil daripada 0,05 . (2) Persepsi nilai berpengaruh langsung sebesar 0,074 terhadap $C C B$. Pengaruh langsung yang positif ini tidak signifikan karena $\mathrm{p}$ value sebesar 0,145 nilainya lebih besar dari 0,05. (3) Kualitas layanan berpengaruh langsung sebesar 0,404 terhadap kepuasan pelanggan. Pengaruh langsung yang positif ini signifikan karena dukungan. (4) p value sebesar $<0,001$ nilainya lebih kecil dari 0,05. (5) Persepsi nilai berpengaruh langsung sebesar 0,346 terhadap kepuasan pelanggan. Pengaruh positif ini signifikan karena $p$ value sebesar $<0,001$ nilainya lebih kecil dari 0,05. (6) Kepuasan pelanggan berpengaruh langsung sebesar 0,371 terhadap $C C B$. Pengaruh positif ini signifikan karena $p$ value sebesar $<0,001$ yang nilainya lebih kecil dari 0,05 .

Pengaruh tidak langsung dapat dimunculkan dengan melakukan evaluasi pada hasil perhitungan WarpPLS dan menghitungnya ke dalam perhitungan $V A F$ (Variance Accounted For). VAF merupakan ukuran seberapa besar variabel pemediasi mampu menyerap pengaruh langsung dari model tanpa pemediasi.

Hasil perhitungan $V A F$ pada model mediasi ke-1 sebesar $35,61 \%$ (VAF berada pada rentang $(20 \%<$ $V A F<80 \%$ ), artinya kepuasan konsumen memiliki peran mediasi secara parsial dalam pengaruh kualitas layanan terhadap $C C B$. Hasil perhitungan $V A F$ pada model mediasi ke-2 sebesar 38,16\% (VAF berada pada rentang $(20 \%<V A F<80 \%)$, artinya kualitas layanan memiliki peran mediasi secara parsial dalam pengaruh persepsi nilai terhadap $C C B$ (Tabel 6).

\section{PEMBAHASAN}

Hasil analisis data memperlihatkan bahwa kualitas layanan berpengaruh positif dan signifikan terhadap Customer Citizenship Behavior (CCB). Artinya, peningkatan Kualitas Layanan akan memberi pengaruh positif dan signifikan terhadap peningkatan Customer Citizenship Behavior (CCB). Hasil penelitian ini sejalan dengan hasil penelitian yang telah dilakukan oleh Helena et, al. (2014) dan Anaza \& Zhao (2013). 
Parasuraman mendefinisikan kualitas layanan sebagai perbedaan antara harapan pelanggan dan persepsi layanan (Parasuraman, 1988). Kualitas layanan yang baik menandakan bahwa harapan-harapan pelanggan telah terpenuhi satu per satu. Harapan-harapan yang terpenuhi menjadikan pelanggan berperilaku sebagaimana yang seharusnya, yaitu pelanggan merasa mendapatkan sesuatu yang berharga dari layanan perusahaan.

Menurut teori pertukaran sosial, para pelanggan akan berpartisipasi dalam serangkaian interaksi interdependen yang mengarah pada kewajiban di antara para pihak pertukaran. Orang-orang yang telah merasakan manfaat dari pihak tertentu mungkin merasa berkewajiban untuk membalas budi pada pihak tersebut (Cropanzano, 2012). Dengan kata lain, pelanggan yang telah merasakan pelayanan yang baik dan terus meningkat dari layanan Go-Jek akan menunjukkan perilaku dengan tanda-tanda positif. Pelanggan akan membela kepentingan atau nama baik Go-Jek bilamana terdapat ancaman negatif yang mengganggu citra Go-Jek. Pelanggan juga akan secara sukarela, tanpa imbalan apa pun dari perusahaan, akan merekomendasikan layanan Go-Jek kepada saudara, teman, ataupun kenalannya. Artinya, peningkatan kualitas layanan akan mendorong peningkatan pula di Customer Citizenship Behavior (CCB).

Hasil analisis data memperlihatkan bahwa Persepsi Nilai berpengaruh positif tetapi tidak signifikan terhadap Customer Citizenship Behavior (CCB). Artinya, perubahan Persepsi Nilai relatif tidak akan memberi pengaruh terhadap peningkatan atau penurunan Customer Citizenship Behavior (CCB). Hasil penelitian ini sejalan dengan hasil penelitian yang telah dilakukan oleh Helena Nguyen, Markus Groth, Gianfranco Walsh, Thorsten Hennig-Thurau (2014). Pengaruh ini bahkan berbalik arah dengan hasil penelitian Chiu et, al. (2017) karena pada penelitian tersebut Customer Citizenship Behavior (CCB) yang memberi pengaruh kepada Persepsi Nilai.

Persepsi Nilai didefinisikan sebagai penilaian menyeluruh konsumen terhadap kegunaan suatu produk (atau layanan) berdasarkan pada persepsi tentang apa yang diterima dan apa yang diberikan (Parasuraman \& Zeithaml, 1988). Pelanggan akan menghitung dan membandingkan antara apa yang dibayarkan dengan apa yang dirasakan dari pelayanan Go-Jek. Evaluasi baik akan menyebabkan peningkatan Persepsi Nilai, dan sebaliknya evaluasi kurang baik akan menurunkan Persepsi Nilai. Nilai yang dirasakan adalah perantara dari manfaat yang dirasakan dari layanan oleh pelanggan, dan berdasarkan perbedaan antara apa yang mereka berikan dalam hal waktu, usaha, dan uang, serta apa yang mereka terima dari kinerja layanan yang diberikan kepada pelanggan. Demikian pula, McDougall dan Levesque (2000) mendefinisikan nilai yang dirasakan sebagai manfaat yang diterima relatif terhadap biaya. Karena fokusnya semata-mata kepada biaya, maka pertimbangan mahal atau murah suatu layanan adalah hal yang menimbulkan Persepsi Nilai di mata pelanggan. Pelanggan bersedia menggunakan kembali bilamana layanan dipersepsikan murah, dan demikian pula sebaliknya. Persepsi Nilai berkaitan hanya dengan uang dan tidak berkaitan dengan perilaku yang dihasilkan yaitu $C C B$ kepada perusahaan Go-Jek.

Hasil analisis data memperlihatkan bahwa kualitas layanan berpengaruh positif dan signifikan terhadap kepuasan pelanggan. Artinya, peningkatan kualitas layanan akan memberi pengaruh positif dan signifikan terhadap peningkatan kepuasan pelanggan. Hasil penelitian ini sejalan dengan hasil penelitian yang telah dilakukan oleh Ishmael Mensah, Rebecca Dei Mensah (2018); Robin Nunkoo, Viraiyan Teeroovengadum, Peta Thomas, Llewellyn Leonar (2017); dan Mohamad Dimyati (2015).

Kualitas layanan menggambarkan suatu upaya yang dilakukan oleh perusahaan Go-Jek dalam melayani konsumennya. Kualitas adalah salah satu hal yang dicari konsumen dalam suatu penawaran dan layanan (Solomon, 2009). Dengan demikian kualitas layanan dapat menjadi cara sebuah organisasi melayani pelanggannya secara baik atau buruk. Parasuraman mendefinisikan kualitas layanan sebagai perbedaan antara harapan pelanggan dan persepsi layanan (Parasuraman, 1988). Peningkatan kualitas layanan artinya peningkatan terpenuhinya harapan pelanggan terhadap layanan yang diberikan oleh Go-Jek dan hal tersebut merujuk kepada pencapaian kepuasan pelanggan. Kepuasan pelanggan adalah faktor paling penting yang mempengaruhi manajemen layanan. Kepuasan pelanggan dapat berupa pembelian berulang (repurchase) dan rekomendasi dari mulut ke mulut (WOM), maka kepuasan pelanggan dianggap penting untuk semua bisnis. Menurut Dube et, al. (1994), kepuasan pelanggan adalah indikator apakah pelanggan akan kembali ke tempat tersebut atau kepuasan pelanggan adalah merupakan sebuah kriteria yang utama untuk menentukan kualitas yang sebenarnya dikirimkan ke pelanggan melalui produk/ jasa dan dengan layanan yang menyertainya. Dengan kata lain, peningkatan kualitas layanan memberi dampak pada peningkatan kepuasan pelanggan.

Hasil analisis data memperlihatkan bahwa persepsi nilai berpengaruh positif dan signifikan terhadap kepuasan pelanggan. Artinya, peningkatan persepsi nilai akan memberi pengaruh positif dan signifikan terhadap peningkatan kepuasan pelanggan. Hasil penelitian ini sejalan dengan hasil penelitian yang telah dilakukan oleh Robin et, al. (2017) dan Chiu et, al. (2017).

Persepsi nilai secara umum didefinisikan sebagai penilaian menyeluruh konsumen terhadap kegunaan suatu produk (atau layanan) berdasarkan pada persepsi tentang apa yang diterima dan apa yang diberikan (Parasuraman \& Zeithaml, 1988). Persepsi nilai adalah perantara dari manfaat yang dirasakan dari layanan oleh pelanggan, dan berdasarkan perbedaan antara 
apa yang mereka berikan dalam hal waktu, usaha, dan uang, serta apa yang mereka terima dari kinerja layanan yang diberikan kepada mereka. Persepsi nilai adalah salah satu yang memiliki banyak faktor penting yang mempengaruhi daya saing organisasi (Ravald dan GroĖnroos, 1996; Parasuraman, 1997). Menurut Woodruff (1997), Persepsi Nilai sering kali dengan mudah disamakan dengan kepuasan, namun kedua hal ini sebenarnya berbeda. Nilai yang dirasakan terjadi pada berbagai tahap proses pembelian, termasuk tahap prapembelian, sedangkan kepuasan secara universal disepakati sebagai evaluasi pasca pembelian dan pascabayar. Ketika persepsi nilai meningkat pada tahap pra-pembelian, maka pelanggan merasakan bahwa harapan-harapan yang ditanamnya kepada produk GoJek meningkat. Oleh karena itu, peningkatan persepsi nilai akan menyebabkan kepuasan pelanggan layanan Go-Jek.

Hasil analisis data memperlihatkan bahwa kepuasan pelanggan berpengaruh positif dan signifikan terhadap $C C B$. Artinya, peningkatan kepuasan pelanggan akan memberi pengaruh positif dan signifikan terhadap peningkatan $C C B$. Hasil penelitian ini sejalan dengan hasil penelitian yang telah dilakukan oleh Van Tonder et, al. (2018) dan Anaza \& Zhao (2013).

Kepuasan pelanggan adalah faktor paling penting yang mempengaruhi manajemen layanan. Kepuasan pelanggan dapat berupa pembelian berulang (repurchase) dan rekomendasi dari mulut ke mulut (WOM), maka kepuasan pelanggan dianggap penting untuk semua bisnis. Menurut Dube et al. (1994), kepuasan pelanggan adalah indikator apakah pelanggan akan kembali ke tempat tersebut atau kepuasan pelanggan adalah merupakan sebuah kriteria yang utama untuk menentukan kualitas yang sebenarnya dikirimkan ke pelanggan melalui produk/jasa dan dengan layanan yang menyertainya. Peningkatan dalam kepuasan pelanggan akan menyebabkan secara sukarela berperilaku positif untuk kepentingan perusahaan Go-Jek. Pelanggan akan secara sukarela membela kepentingan GoJek, mempromosikan Go-Jek dan membicarakan hal-hal positif mengenai Go-Jek. Dengan kata lain, meningkatnya kepuasan pelanggan akan secara otomatis meningkatkan $C C B$.

Hasil analisis data memperlihatkan bahwa kepuasan pelanggan memiliki peran mediasi sebesar $35,61 \%$ pada hubungan kualitas layanan dengan $C C B$. Dengan kata lain, kepuasan pelanggan memediasi secara parsial pada hubungan kualitas layanan dengan $C C B$. Hal ini didukung dengan temuan sebelumnya dimana secara langsung kualitas layanan berpengaruh signifikan terhadap $C C B$. Pengaruh tersebut kemudian diperkuat oleh pengaruh kualitas layanan yang secara langsung memberi pengaruh signifikan terhadap $C C B$.

Hasil analisis data memperlihatkan bahwa kepuasan pelanggan memiliki peran mediasi sebesar $38,16 \%$ pada hubungan persepsi nilai dengan $C C B$. Dengan kata lain, kepuasan pelanggan memediasi secara parsial pada hubungan persepsi nilai dengan $C C B$. Hal ini didukung dengan temuan sebelumnya dimana secara langsung persepsi nilai tidak berpengaruh signifikan terhadap $C C B$, tetapi pengaruh tersebut kemudian ditambahkan oleh pengaruh kualitas layanan yang secara langsung memberi pengaruh signifikan terhadap $C C B$.

\section{KESIMPULAN}

Kualitas layanan berpengaruh positif dan signifikan terhadap Customer Citizenship Behavior (CCB). Artinya, peningkatan kualitas layanan akan memberi pengaruh positif dan signifikan terhadap peningkatan $C C B$. Persepsi nilai berpengaruh positif tetapi tidak signifikan terhadap $C C B$. Artinya, perubahan persepsi nilai relatif tidak akan memberi pengaruh terhadap peningkatan atau penurunan $C C B$. Kualitas layanan berpengaruh positif dan signifikan terhadap kepuasan pelanggan. Artinya, peningkatan kualitas layanan akan memberi pengaruh positif dan signifikan terhadap peningkatan kepuasan pelanggan.

Persepsi nilai berpengaruh positif dan signifikan terhadap kepuasan pelanggan. Artinya, peningkatan persepsi nilai akan memberi pengaruh positif dan signifikan terhadap peningkatan kepuasan pelanggan. Kepuasan pelanggan berpengaruh positif dan signifikan terhadap $C C B$. Artinya, peningkatan kepuasan pelanggan akan memberi pengaruh positif dan signifikan terhadap peningkatan $C C B$. Kepuasan pelanggan memiliki peran mediasi sebesar $35,61 \%$ pada hubungan kualitas layanan dengan $C C B$. Dengan kata lain, kepuasan pelanggan memediasi secara parsial pada hubungan kualitas layanan dengan $C C B$. Kepuasan pelanggan memiliki peran mediasi sebesar $38,16 \%$ pada hubungan persepsi nilai dengan $C C B$. Dengan kata lain, kepuasan pelanggan memediasi secara parsial pada hubungan persepsi nilai dengan $C C B$.

\section{DAFTAR PUSTAKA}

Agyapong, D., 2010. Micro, small and medium enterprises' activities, income level and poverty reduction in ghana-A synthesis of related literature. International Journal of Business and Management, 5(12), p. 196.

Anaza, N. and Zhao, J., 2013. Encounter-based antecedents of e-customer citizenship behaviors. Journal of Services Marketing, 27(2), pp.130-140.

Baker, D.A. and Crompton, J.L., 2000. Quality, satisfaction and behavioral intentions. Annals of tourism research, 27(3), pp.785-804.

Bettencourt, L.A., 1997. Customer voluntary performance: Customers as partners in service delivery. Journal of retailing, 73(3), pp.383-406.

Boksberger, Philipp E., and Lisa Melsen. 2011. Perceived Value: A Critical Examination of Definitions, 
Concepts and Measures for The Service Industry. Journal of Services Marketing, Vol 25, No. 3, pp: 229-240

Bove, L. L., Pervan, S. J., Beatty, S. E \& Shiu, E. 2009. Service Worker Role in Encouraging Customer Organizational Citizenship Behaviors. Journal of Business Research. Vol. 62, No. 7, pp: 698-705.

Chelminski, P. and Coulter, R.A., 2011. An examination of consumer advocacy and complaining behavior in the context of service failure. Journal of services marketing, 25(5), pp.361-370.

Chiu, W., Shin, S. and Lee, H.W., 2017. Value Co-Creation in Fitness Centers: The Role of Customer Citizenship Behavior on Perceived Value, Satisfaction, and Repurchase Intention. In Handbook of Research on Strategic Alliances and Value Co-Creation in the Service Industry ( $p p$. 415-430). IGI Global.

Cropanzano, R., Becker, W.J. and Feldman, J., 2012. The effect of moods and discrete emotions on negotiator behavior. In The psychology of negotiations in the 21st century workplace (pp. 177-216). Routledge.

Deng, W.J., Yeh, M.L. and Sung, M.L., 2013. A customer satisfaction index model for international tourist hotels: Integrating consumption emotions into the American Customer Satisfaction Index. International Journal of Hospitality Management, 35, pp.133-140.

Dimyati, M., 2015. The role of customer satisfaction in mediating marketing communication effect on customer loyalty. Researchers World, 6(4), p.75.

Dube, L. \& Morgan, M.S. 1994. Trend Effect and Gender Differences In Retrospective Judgments of Consumtion Emotions. Journal of Consumer Research. Pp: 156-162.

Eggert, A., \& Ulaga, W. 2002. Customer perceived value: a substitute for satisfaction in business market. Journal of Business \& Industrial Marketing, Vol 17. Iss 2/3, pp: 107-118

Eugene, W. Anderson, Claes Fornell, Donald R. Lehmann. 1994. Journal of Marketing. Vol. 58, No. 3, pp. 53-66.

Fowler, J.G., 2013. Customer citizenship behavior: an expanded theoretical understanding. International Journal of Business and Social Science, 4(5).

Ghozali dan Fuad. 2011. Structural Equation Modelling. Semarang : BP UNDIP

Gilde, C., Pace, S., Pervan, S.J. and Strong, C., 2011. Examining the boundary conditions of customer citizenship behaviour: a focus on consumption ritual. Journal of strategic Marketing, 19(7), pp.619-631.

Holbrook, M. B. 1994. The nature of customer value: an anthology of services in the consumption experience. Service Quality: New Directions in Theory and Practice. Pp: 21-71.

Jamshidi, D., Keshavarz, Y., Kazemi, F. and
Mohammadian, M., 2018. Mobile banking behavior and flow experience: An integration of utilitarian features, hedonic features and trust. International Journal of Social Economics, 45(1), pp.57-81.

Joan, Giese, L \& Joseph, A, Cote. 2000. Defining Customer Satisfaction. Vol 2000.

Kotler, Philip,Kevin Lane Keller. 2012. Manajemen Pemasaran. Alih bahasa: Bob Sabran. Jakarta: PT Indeks.

Lawler, E.J., 2001. An affect theory of social exchange. American Journal of Sociology, 107(2), pp.321-352.

Leal, R.P.C. and Saito, R., 2003. Finanças corporativas no Brasil. RAE eletrônica, 2(2), pp.1-15.

Lengnick-Hall, C.A., Claycomb, V.C. and Inks, L.W., 2000. From recipient to contributor: examining customer roles and experienced outcomes. European journal of marketing.

Liljander, V. and Strandvik, T., 1995. The relation between service quality, satisfaction and intentions. Managing service quality, 1, pp.45-61.

McDougall, G. H. G., dan Levesque, T. J. 2000. Customer Satisfaction With Services : Putting Perceived Value Into The Equation. Journal of Service Marketing. Vol. 14, No. 5.

Mensah, I. and Dei Mensah, R., 2018. Effects of Service Quality and Customer Satisfaction on Repurchase Intention in Restaurants on University of Cape Coast Campus.

Nguyen, H., Groth, M., Walsh, G. and Hennig-Thurau, T., 2014. The impact of service scripts on customer citizenship behavior and the moderating role of employee customer orientation. Psychology \& Marketing, 31(12), pp.1096-1109.

Parasuraman, Valarie A. Zeithaml, and Leonard L. Berry. 1988. SERVQUAL: A Multiple-Item Scale for Measuring Consumer Perceptions of Service Quality. Journal of Retailing. Vol 64, pp: 12-37

Ravald, A. and Grönroos, C. 1996. The value concept and relationship marketing, European Journal of Marketing, Vol. 30 No. 2, pp. 19-30.

Robin, Nunkoo. Viraiyan, Teeroovengadum. Peta, Thomas. Llewellyn, Leonard. 2017. Integrating Service Quality As A Second-Order Factor In A Customer Satisfaction And Loyalty Model. South Africa: International Journal of Contemporary Hospitality Management.

Solomon, R. Michael. 2009. Customer Behaviour: A European Perspective. New Jersey: Financial Times Prentice Hall.

Tam, J.L.M. 2000. The effects of service quality, perceived value and customer satisfaction on behavioral intentions, Journal of Hospitality and Leisure Marketing, Vol. 6 No. 4, pp. 31-43.

Van Tonder, E., Petzer, D.J., Van Vuuren, N. and De Beer, L.T., 2018. Perceived value, relationship quality and positive WOM intention in banking. International Journal of Bank Marketing, 36(7), 
pp.1347-1366.

Woodruff, R.B., 1997. Customer value: the next source for competitive advantage. Journal of the academy of marketing science, 25(2), p.139.

Yi, Y. and Gong, T. 2013. Customer value co-creation behavior: scale development and validation, Journal of Business Research, Vol. 66 No. 9, pp. 1279-1284 Yoon, Y.S., Lee, J.S. and Lee, C.K., 2010. Measuring festival quality and value affecting visitors,

Tabel 1. Uji Validitas Diskriminan

\begin{tabular}{lccc}
\hline \multicolumn{1}{c}{ Variabel } & AVE & Nilai Kritis & Keterangan \\
\hline Kualitas layanan & 0,613 & 0,5 & Valid \\
Persepsi nilai & 0,588 & 0,5 & Valid \\
Kepuasan pelanggan & 0,563 & 0,5 & Valid \\
Customer Citizenship Behavior & 0,635 & 0,5 & Valid \\
\hline
\end{tabular}

Tabel 2. Uji Reliabilitas Pada Variabel Laten

\begin{tabular}{llccr}
\hline No & $\quad$ Variabel & $\begin{array}{c}\text { Composite } \\
\text { Reliability } \\
\text { Coefficient }\end{array}$ & $\begin{array}{c}\text { Cronbach } \\
\text { Alpha }\end{array}$ & Keterangan \\
& & 0,888 & 0,842 & Reliabel \\
\hline 1. & Kualitas layanan & 0,877 & 0,824 & Reliabel \\
2. & Persepsi nilai & 0,865 & 0,804 & Reliabel \\
3. & Kepuasan pelanggan & 0,933 & 0,918 & Reliabel \\
\hline 4. & Customer Citizenship Behavior & 0,933 & & \\
\hline
\end{tabular}

Tabel 3. Evaluasi Goodness OfFit Pada Model Persamaan Struktural

\begin{tabular}{ll}
\hline \multicolumn{1}{c}{ Parameter } & \multicolumn{1}{c}{ Koefisien } \\
\hline Average path coefficient & $=0,267 ; \mathrm{P}<0,001$ \\
Average $R$-squared & $=0,290 ; \mathrm{P}<0,001$ \\
Average adjusted $R$-squared & $=0,281 ; \mathrm{P}<0,001$ \\
Average block VIF & $=1,200 ;$ acceptable if $<=5 ;$ ideally $<=3,3$ \\
\hline
\end{tabular}

Tabel 4. Goodness Of Fit Antar Variabel Laten

\begin{tabular}{lccc}
\hline \multicolumn{1}{c}{ Variabel } & $\begin{array}{r}\text { Nilai R- N i l a i } \\
\text { Square }\end{array}$ & Q-Square & Keterangan \\
\hline $\begin{array}{l}\text { Kualitas layanan } \\
\text { Persepsi nilai }\end{array}$ & & & \\
Kepuasan pelanggan & 0,344 & 0,345 & Baik \\
Customer Citizenship Behavior & 0,235 & 0,238 & Baik \\
\hline
\end{tabular}

Tabel 5. Pengaruh Persamaan Struktural

\begin{tabular}{ccc}
\hline Hubungan & Loading & P Value \\
\hline $\mathrm{SQ}=>C C B$ & 0,140 & 0,022 \\
$\mathrm{PV}=>C C B$ & 0,074 & 0,145 \\
$\mathrm{SQ}=>$ SATF & 0,404 & $<0,001$ \\
$\mathrm{PV}=>$ SATF & 0,346 & $<0,001$ \\
$\mathrm{SATF}=>C C B$ & 0,371 & $<0,001$ \\
\hline
\end{tabular}

satisfaction and loyalty using a structural approach. International Journal of Hospitality Management, 29(2), pp.335-342.

Youjae, Yi. 2014. Customer Value Creation Behavior. Routledge of Taylor \& Francis Group, an informa business.

Zeithaml, V. A. and Bitner, M.J. 2000. Services Marketing: Integrating Customer Focus Across Firm, 2nd ed. New York: McGraw-Hill

Tabel 6. Perhitungan Pengaruh Mediasi

\begin{tabular}{ccc}
\hline $\begin{array}{c}\text { Pengaruh antar } \\
\text { Variabel }\end{array}$ & $\begin{array}{c}\text { Mediasi dari Serv_ } \\
\text { Qual }\end{array}$ & $\begin{array}{c}\text { Mediasi dari } \\
\text { Perc_Val }\end{array}$ \\
\hline P13 & 0,271 & 0,208 \\
P12 & 0,404 & 0,346 \\
P23 & 0,371 & 0,371 \\
P12 P23 & 0,14988 & 0,128366 \\
$V A F$ & $35,61 \%$ & $38,16 \%$ \\
\hline
\end{tabular}

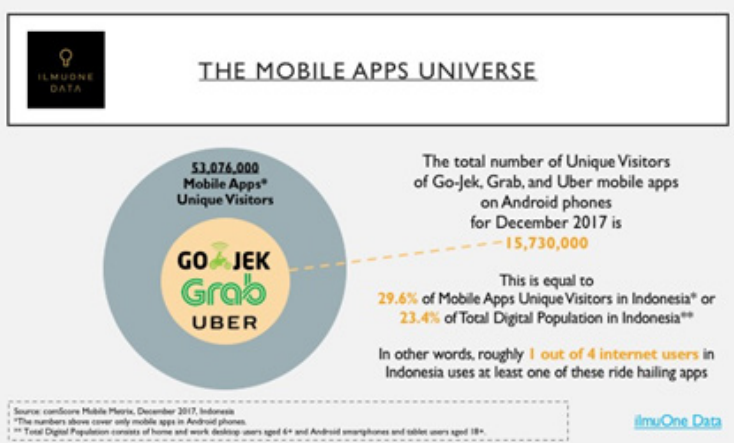

(Sumber: ComScore, IlmuOne Data)

Gambar 1. Gambaran Pengguna Transportasi Online Hingga Desember 2017

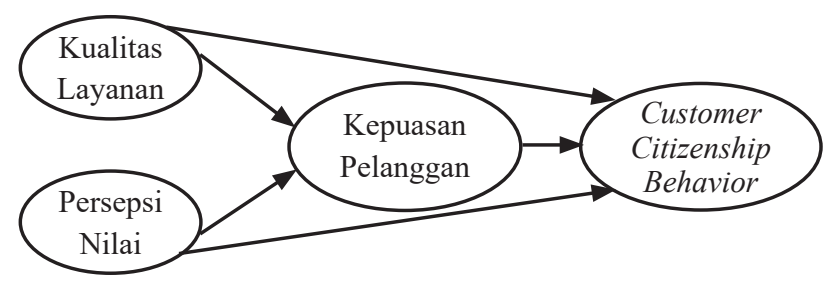

Gambar 2. Kerangka Pemikiran 